16. Дацій О. І. Розвиток інноваційної діяльності в агропромисловому виробництві України / Олександр Іванович Дацій. - К. : ННЦ ІАЕ, 2004. - 428 с.

17. Гудзь В. П. Адаптивні системи землеробства : підручник / [В. П. Гудзь, І. Д. Примак та ін.]. - К. : Центр учб. л-ри, 2007. - 334 с.

Ясенчук Неля, Зинчук Николай. Влияние интенсивных технологий на агроэкологическое состояние почв Волыни. Акцентируется внимание на хозяйственных и агроэкологических балансах за активного внедрения интенсивных технологий растениеводства в Волынской области. Выявлены общие негативные тенденции относительно показателей плодородия почв, недостаточных уровней применения органических и минеральных удобрений, а также обратные к ним хозяйственные результаты, характеризуемые ростом урожаев.

Поднята проблема несоответствия реальной ситуации в агропроизводстве фундаментальным научным положениям. Несмотря на то, что происходит внедрение интенсивных технологий и наращивание производства продукции, одновременно фиксируются опасные деградационные процессы истощения почв на фоне недостаточного их обеспечения агрохимическими и агробиологическими ресурсами.

Ключевые слова: интенсивные технологии, почва, плодородие, урожайность, минеральные и органические удобрения, баланс гумуса и питательных веществ.

Iasenchuk Nelia, Zinchuk Mykola. Influence of the Intensive Technologies on the Agro-ecological Condition of the Soils of Volyn. The attention has been paid to the economic and agro-ecological balances under the conditions of the active implementation of the crop intensive technologies in the Volyn region. General negative tendencies of the indicators of the soil fertility and insufficient usage of organic and mineral fertilizers were described. The economic results that are characterized by the rising harvests were pointed out too.

The problem of the discrepancy of the actual situation in the agricultural production with fundamental scientific principles was pointed out. Although the implementation is intensive technologies and production capacity, while fixed dangerous depletion of soil degradation processes against the background of insufficient provision of agrochemical and agrobiological resources.

Key words: intensive technologies, soil, fertility, yield, mineral and organic fertilizers, a balance of humus and nutrients.

Стаття надійшла до редколегії 28.03.2016 p.

УДК 504:528.9(477-25)

Галина Стець,

Наталія Волошина

\title{
Біоіндикаційне картографування техногенно трансформованих територій м. Кисва
}

Уперше розглянуто питання біоіндикаційного картографування еколого-паразитологічного стану техногенно трансформованих територій. Описано та апробовано методику створення картосхем місцевості щодо паразитарного забруднення на території міста Києва.

Ключові слова: біоіндикаційне картографування, еколого-паразитологічний стан, техногенно трансформовані території, Toxосаra canis.

Постановка наукової проблеми та її значення. Міста належать до важливих техногенно трансформованих екосистем. Особливістю довкілля міст є поєднання природних та антропогенних компонентів, взаємозв'язок яких забезпечується гетерогенністю умов існування живих організмів. Техногенне забруднення різних компонентів довкілля - один з очікуваних впливів людства на природу, що у своїй структурі й динаміці має глобальні тенденції та проявляється специфічно для кожної окремо взятої території [4]. Актуальною донині залишається розробка прийомів картографічного забезпечення науково обгрунтованої оцінки стану техногенно трансформованих територій за допомогою виявлення структури забруднення різних компонентів довкілля для запобігання розвитку антропозоонозних захворювань, зокрема токсокарозу. Згідно з галузевою статистичною звітною формою № 40-здоров Міністерства охорони здоров’я України, за останнє десятиліття кількість випадків захворювань на токсокароз серед населення нашої країни зросла вп'ятеро (від 74 (2005 р.) до 422 (2013 р.)).

(C) Стеиь Г., Волошин Н, 2016 
Аналіз досліджень цієї проблеми. Відомі способи картографування забруднення окремих компонентів навколишнього природного середовища, зокрема поверхневих та підземних вод, повітря. Вітчизняні дослідники використовували картографічні прийоми для візуалізації біомоніторингових досліджень, але об'єктами індикації зазвичай виступали рослини $[1,2]$. Також потрібно зазначити, що паразитарне забруднення об'єктів довкілля є маловивченим напрямом, а в аспекті біоіндикації досі не розглядалось. На основі літературного огляду можна стверджувати, що методична база біоіндикаційного картографування існує, проте вона не апробована в межах вивчення паразитарного забруднення. Якщо спробувати іiї апробувати до нього, то вона має низку недоліків. Наявні методи орієнтовані лише на місця розміщень промислових потужностей $\mathrm{i}$, як наслідок, отриманий результат використовують на обмежених територіях; також існують часові та просторові обмеження в рамках дослідження. Тож і результати можна отримати лише в певний визначений період; суттєво обмежено використання біологічного виду в якості біоіндикатора в конкретних природних умовах. Потрібно зазначити, що при проведенні досліджень зазвичай виділяють фонові ділянки, що $є$ неможливим при дослідженні паразитарного забруднення, яке поширене по всій території через основного хазяїна - домашніх хижих тварин.

Мета дослідження - розробка й апробація способу біоіндикаційного картографування техногенно трансформованих територій міста Києва з використанням паразитичної нематоди T. canis.

Матеріали та методи. Дослідження грунту здійснювали в м. Києві протягом 2015 p. i проводили за загальноприйнятими методами: польові, камеральні, спеціальні методики біологічних (екологічних), лабораторних (гельмінтологічні) та статистично-математичних аналізів. Матеріалом слугували відібрані 1160 проб грунту.

Виклад основного матеріалу й обгрунтування отриманих результатів дослідження. Нами запропоновано та описано спосіб біоіндикаційного картографування еколого-паразитологічного стану техногенно трансформованих територій, розроблено й використано вперше на території міста Києва для виявлення осередків паразитарного забруднення. На нашу думку, він $є$ одним з основних у біомоніторингових дослідженнях еколого-паразитологічної ситуації техногенно трансформованих територій.

В основі пропонованого способу лежить розробка біомоніторингу на основі біоіндикації, що володіє достатньою чутливістю до змін середовища з використанням візуалізації ступеня паразитарного забруднення та дає змогу візуально оцінити ступінь небезпеки й рівень забруднення. На картосхемі позначають місця фіксації розповсюдженого біологічного об'єкта - зоонозного геогельмінту домашніх хижих (собак) Toxосara canis за морфологічними ознаками.

Спосіб біоіндикаційного картографування еколого-паразитологічного стану техногенно трансформованих територій оснований на тому, що обирають обгрунтовані біомоніторингові ділянки, визначають необхідну кількість проб, яку потрібно зібрати, фіксують кількісний і якісний склад проб та на основі отриманих результатів візуалізують їх на картосхемах за допомогою програмного забезпечення.

Картографічні підходи найбільш ефективні на рівні адміністративного району. Такий масштаб дослідження дає змогу об'єднати детальність відображуваної інформації, щоб наочно передати загальні закономірності розвитку процесів забруднення, а при використанні сучасних комп'ютерних засобів, це значно підвищує ефективність й оперативність аналізу еколого-географічної інформації [3].

Аналіз та узагальнення досвіду картографування забруднень територій на рівні адміністративних районів, що особливо актуально при комплексних дослідженнях, грунтується на принципах системного й геоінформаційного картографування, що дає змогу оперативно та всебічно охарактеризувати систему формування процесів, виявити причини й умови формування їхньої структури. Тому в нашій роботі використано адміністративно-територіальний поділ міста Києва. Для апробації методичних розробок до паразитарного забруднення щодо районування досліджуваних територій згідно з адміністративно-територіальним устроєм міста Києва розраховано кількість дослідних ділянок відповідно до чисельності населення в кожному районі окремо (табл. 1).

При оцінці екологічного стану міста 3 населенням 1 млн осіб рекомендовано поділити його територію на 20 квадратів із виділенням у кожному 10-20 пунктів спостережень залежно від рівня екологічної напруженості; такий розподіл узято за основу при розрахунку їх кількості. Станом на 01 січня 2015 р. населення столиці України становило 2889838 осіб. Кількість дослідних ділянок у кожному районі залежала від чисельності населення й, відповідно, площі дослідних ділянок були piзні. 


\section{Розподіл дослідних ділянок}

\begin{tabular}{|l|c|c|c|c|}
\hline $\begin{array}{c}\text { Адміністративний } \\
\text { район } \\
\text { м. Кисва }\end{array}$ & $\begin{array}{c}\text { Площа } \\
\text { району, к.2 }\end{array}$ & $\begin{array}{c}\text { Населення } \\
\text { району, } \\
\text { осіб }\end{array}$ & $\begin{array}{c}\text { Кількість } \\
\text { дослідних ділянок у } \\
\text { районі }\end{array}$ & $\begin{array}{c}\text { Середня площа } \\
\text { однісї ділянки, км }\end{array}$ \\
\hline Голосіївський & 156 & 244625 & 5 & 31,2 \\
\hline Оболонський & 110 & 319697 & 6 & 9,3 \\
\hline Печерський & 27 & 149514 & 3 & 8,0 \\
\hline Подільський & 34 & 196466 & 4 & 14,4 \\
\hline Святошинський & 101 & 340424 & 7 & 5,7 \\
\hline Солом'янський & 40 & 360998 & 7 & 19,1 \\
\hline Шевченківський & 25 & 227795 & 5 & 21,1 \\
\hline Дарницький & 134 & 329883 & 7 & 9,6 \\
\hline Деснянський & 148 & 367254 & 7 & - \\
\hline Дніпровський & 67 & 353182 & 7 & \\
\hline Усього & 842 & 2889838 & 58 & \\
\hline
\end{tabular}

Із табл. 1 очевидно, що кількість та розміри біомоніторигових ділянок залежали від чисельності населення. Найбільшу кількість - сім - визначено у Святошинському, Солом'янському, Дарницькому, Деснянському й Дніпровському, а найменшу - три - у Печерському.

За допомогою пакетних програм Excel проведено розрахунки та виділено 58 дослідних ділянок, що передбачало збір по 580 проб грунту двічі на рік. Програми MapInfo та AutoCad дали змогу візуалізувати дослідні ділянки на карті міста Києва масштабом 1:25 000 загалом і за районами окремо. Далі на основі отриманої картосхеми зібрано проби грунту, 10 - у кожній дослідній ділянці, із фіксацією адреси, для формування карт та повторного взяття проби. Результати представлені за допомогою геометричних елементів різних кольорів залежно від результату дослідженої проби й унаочнено осередки паразитарного забруднення всієї території загалом і за районами окремо (рис. 1).

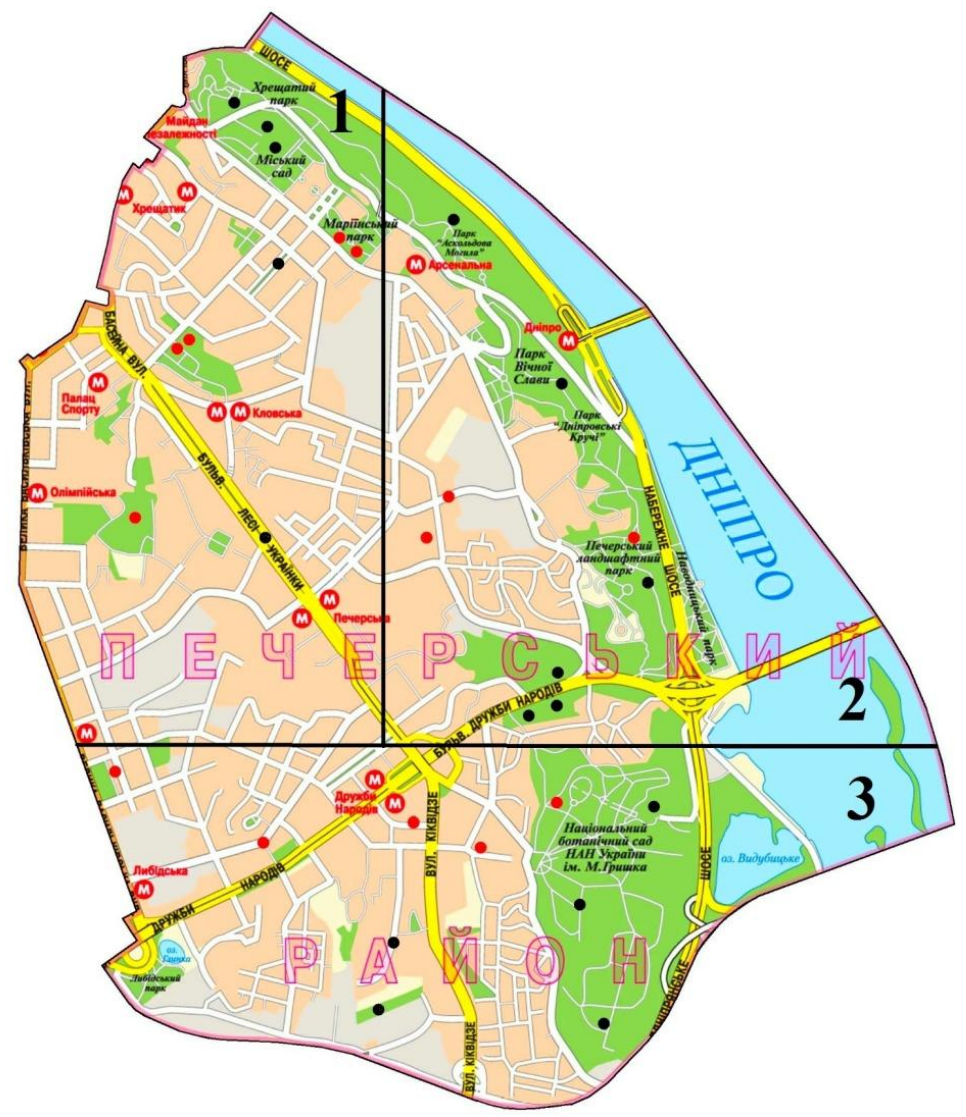

Рис. 1. Еколого-паразитологічний стан техногенно трансформованих територій (на прикладі Печерського адміністративного району м. Києва) 
Із рис. 1 очевидно, що у відсотковому співвідношенні 43,33 \% території забруднено, тобто в 13 із 30 проб грунту зареєстровано яйця токсокар. За отриманими даними потрібне проведення дегельмінтизації на конкретних територіях для запобігання зараженню населення й домашніх хижих.

Висновки й перспективи подальших досліджень. Технічним результатом виконаної роботи $\epsilon$ отримання картосхем техногенно трансформованих територій на основі візуалізації результатів дослідження проб грунту на вміст токсокар. Використання таких тематичних картосхем дає змогу оцінити реальний рівень небезпеки щодо зараження населення на токсокароз. Позитивний ефект проявляється в тому, що запропонований спосіб уможливлює диференційоване тестування забруднення грунтів токсокарами. Застосування цього способу дасть змогу більш точно виділити зони забруднення токсокарами, проводити оцінку та постійний моніторинг стану техногенно трансформованих територій, оцінювати рівень забруднення, контролювати, експертувати та планувати антропогенну діяльність на місцевості.

Отже, розроблений спосіб еколого-паразитологічного картографування техногенно трансформованих територій показує можливість візуалізації індикації стану територій із використанням зоонозного геогельмінту домашніх хижих (собак) Toxocara canis.

\section{Джерела та література}

1. Методичні рекомендації «Обстеження та районування території за ступенем впливу антропогенних чинників на стан об'єктів довкілля з використанням цитогенетичних методів» // Наказ МОЗ України від 13.03.2007. - № 116.

2. Пат. 36844 Україна, МПК А01G7/00. Спосіб фітоекологічного картування техногенно забруднених територій / Г. І. Хархота, О. З. Глухов, С. І. Прохорова. - № 200806780 ; заявл. 19.05 .2008 ; опубл. 10.11.2008 // Бюл. № 21. - 2008. - 14 c.

3. Прасолова А. И. Комплексное картографирование загрязнения территории административного району : дис. ... канд. геогр. наук : 25.00.33 / Прасолова Анна Ивановна ; Государственный университет им. М. В. Ломоносова. - М., 2001 . -178 с.

4. Сущук А. А. Влияние техногенного загрязнения промышленных центров Карелии на сообщества почвенных нематод / А. А. Сущук, Л. И. Груздева // Известия ПГПУ им. В. Г. Белинского. - 2011. - № 25. C. $445-452$.

Стец Галина, Волошина Наталия. Биоиндикационное картографирование техногенно трансформированных территорий г. Киев. В работе исследованы актуальные вопросы отсутствия разработанных методик биоиндикационного картографирования техногенно трансформированных территорий, включающее периодическую фиксацию распространенных биологических объектов по морфологическим признакам и нанесения на карту геометрических элементов, по которым определяют состояние окружающей среды; как биологический объект был использован зоонозный геогельминт домашних хищных (собак) Toxocara canis, который регистрируют в пробах почвы и с помощью маркированых точек наносят на карту, составляют экологические картосхемы местности. На примере г. Киев проверено адекватность данного способа. Использование таких тематических картосхем позволяет оценить реальный уровень безопасности по заражению населения токсокарозом. Положительный эффект проявляется в том, что предложенный способ позволяет дифференцированно тестировать загрязнения почв токсокарами. Использование способа позволит более точно выделить зоны загрязнения токсокарами, проводить оценку и постоянный мониторинг состояния техногенно трансформированных территорий, оценивать уровень загрязнения, контролировать, экспертировать и планировать антропогенную деятельность на местности.

Ключевые слова: биоиндикационное картографирование, эколого-паразитологическое состояние, техногенно трансформированные территории, Toxocara canis.

Stets Galyna, Voloshyna Natalia. Bioindicative Mapping of Technogenic Transformed Territories of Kiev. The article investigated actual questions the lack of developed methods bioindication mapping of technogenic transformed territories, including periodic fixing state of widespread biological objects by morphological characters and mapping geometric elements, which determine the state of the environment; as a biological object was used zoonotic geohelminthes domestic carnivores (dogs) Toxocara canis, which is recorded in soil samples and using a marking point is applied to the card, constitute environmental schematic maps areas. We tested the adequacy of the method for example Kyiv. The positive effect is that the proposed method enables a differentiated test contamination of soil by toxocara. Using the method will more accurately identify the contamination zone by toxocara, assess and constant monitoring of technogenic transformed territories, to assess the level of contamination, control and plan human activities in the area.

Key words: bioindication mapping, ecological and parasitological state, technologically transformed territories, Toxocara canis.

Стаття надійшла до редколегії 28.03.2016 p. 